\title{
Immune complexes, rheumatoid factors, and cellular immunological parameters in patients with giant cell arteritis
}

\author{
BO-ERIC MALMVALL ${ }^{1}$, BENGT-ÅKE BENGTSSON ${ }^{2}$, \\ LARS-ÅKE NILSSON ${ }^{3}$, AND LARS-MAGNUS BJURSTEN ${ }^{3}$
}

From the ${ }^{1}$ Department of Infectious diseases, East Hospital, the ${ }^{2}$ Departments of Medicine I and II, Sahlgren's Hospital, and the ${ }^{3}$ Department of Medical Microbiology, University of Göteborg, Sweden

SUMMARY Circulating immune complexes were found in 2 of 15 patients with giant cell arteritis (GCA) by using a solid phase Clq enzyme linked immunoabsorbent assay (ELISA). The prevalence in controls was $5 \%$. Rheumatoid factor could be demonstrated in 2 out of 27 patients and in $11 \%$ of the controls by using a similar ELISA technique. The prevalence of $\mathrm{T}$ cells in blood was similar in 25 patients with GCA and in controls. The blood lymphocyte blastogenic response to the mitogens, phytohaemagglutinin, concanavalin-A, and pokeweed mitogen did not differ in 25 untreated patients compared with controls. Stimulation of lymphocytes by arterial homogenates was tested in 8 patients. In no case could a significant stimulation be obtained. We conclude that immune complexes and rheumatoid factors are present in the same low frequency in GCA patients as in the normal population, and that the studied parameters of cellular immunity appear to be normal.

Several authors have suggested that immunological mechanisms may be involved in the pathogenesis of giant cell arteritis (GCA). ${ }^{1-4}$ Our group has found that serum levels of IgG and total serum complement, as well as factors $\mathrm{C} 3$ and $\mathrm{C} 4$, are slightly elevated in this disease. ${ }^{5}$ Other workers have demonstrated immunoglobulin and anti-immunoglobulin (rheumatoid factors) in the arterial wall, ${ }^{67}$ findings which were interpreted as indicating either deposition of immune complexes or the occurrence of antigenantibody reactions within the vessel wall.

Cell mediated immune mechanisms have also been proposed as being involved in the pathogenesis of GCA. Hazleman et al. ${ }^{8}$ found that blood lymphocytes from patients with GCA in vitro showed a higher transformation response to artery antigen than lymphocytes from controls, a finding which has been questioned by others, however. ${ }^{9} 10$

In this study the presence of circulating immune complexes and rheumatoid factors (RF) was investigated by 2 enzyme linked inmumosorbent assays (ELISA). We have also studied the prevalence

Accepted for publication 2 July 1980

Correspondence to $\mathrm{Dr}$ Bo-Eric Malmvall, Göteborgs Universitet, Infektionskliniken, Östra sjukhuset, 41685 Göteborg, Sweden. of $\mathrm{T}$ cells in peripheral blood and the reactivity of blood lymphocytes to different mitogens and to arterial wall homogenate.

\section{Materials and methods}

\section{PATIENTS}

The studies were performed on untreated GCA patients during the years $1975-8$ at the Department of Internal Medicine III, Sahlgren's Hospital, and at the Department of Infectious Diseases, East Hospital, Göteborg. A temporal artery biopsy was performed on all patients. If the biopsy showed mononuclear cell infiltration and destruction of the internal elastic membrane, the patients were regarded as biopsypositive. Biopsy-negative patients were included if certain clinical criteria, defined earlier, were fulfilled. ${ }^{11}$ The patients were classified by symptoms at diagnosis into 4 clinical groups: temporal arteriiis, combined temporal arteritis and polymyalgia rheumatica, polymyalgia rheumatica, and general symptoms only. ${ }^{12}$ The mean age was 71.6 years (range 58-85 years). Not all the immunological tests were available during the entire period of study, and the number of patients studied with the different tests therefore varies. 


\section{CONTROLS}

People aged 70 were selected at random from a gerontological and geriatric population study in Göteborg ${ }^{13}$ and used as controls.

\section{IMMUNE COMPLEXES}

Determination of immunecomplexes by ELISA was performed as previously described. ${ }^{14}$ Polystyrene tubes were coated by incubation with a solution containing $50 \mathrm{ng}$ purified $\mathrm{Clq}$ in $0.5 \mathrm{ml}$ of $0.05 \mathrm{M}$ phosphate buffered saline, $\mathrm{pH} 7 \cdot 2$, for 3 hours at $37^{\circ} \mathrm{C}$. After rinsing away the excess of $\mathrm{Clq}, 0.5 \mathrm{ml}$ of the serum samples was added in 10-fold serial dilutions. Incubation was performed by gently shaking the tubes at $37^{\circ} \mathrm{C}$ for 3 hours. After a further rinsing rabbit antihuman $\mathrm{Clq}$ (kindly provided by Dr Bengt Johansson, Lund, Sweden) was added to the tubes to cover unoccupied $\mathrm{Clq}$ antigenic determinants. The tubes were incubated for another 3 hours at $37^{\circ} \mathrm{C}$. After a further rinsing rabbit antisera against human $\operatorname{IgG}, \operatorname{IgA}$, and $\operatorname{IgM}$ (Dakopatts AS, Copenhagen, Denmark), conjugated with alkaline phosphatase, were added. After incubation on a roller drum for 16 hours at room temperature and subsequent rinsing the remaining enzyme activity was determined by adding paranitrophenyl phosphate (Sigma Chemical Company, Saint Louis, Missouri, USA) $1 \mathrm{mg} / \mathrm{ml}$ in $1 \mathbf{M}$ diethanolamine buffer, $\mathrm{pH} 9 \cdot 8$, containing 0.0011 $\mathbf{M ~} \mathrm{MgCl}_{2}$. The enzymatic reaction was interrupted after 100 minutes by addition of $0.1 \mathrm{ml} 3 \mathrm{M} \mathrm{NaOH}$, and the light absorption at $405 \mathrm{~nm}$ was registered. Optical densities (OD) were recorded for 1:10 dilutions of the tested serum samples and compared with the OD obtained for a pool of positive sera..$^{15}$ Sera giving an OD higher than $25 \%$ for IgG, $35 \%$ for IgA, and $75 \%$ for IgM of the OD for the reference pool of sera were regarded as positive. All dilutions and rinses were done with $0.05 \mathrm{M}$ phosphate buffered saline, pH $7 \cdot 2$, containing $0.5 \%$ Tween 20 , except for the coating procedure, where Tween 20 was excluded.

\section{RHEUMATOID FACTORS}

Polystyrene tubes were coated by incubation with $10 \mu \mathrm{g}$ bovine serum albumin (BSA) in $0.5 \mathrm{ml} 0.15 \mathrm{M}$ phosphate buffered saline for 2 hours at room temperature. After rinsing, rabbit anti-BSA serum diluted in 1/5000 in PBS-Tween was added. After further rinsing, the serum sample to be tested, diluted $1: 100$ or 1:1000, was added and the presence of bound human immunoglobulins was determined as described above for the $\mathrm{Clq}$ immunosorbent test. The results were expressed as the OD at $405 \mathrm{~nm}$ for $1 / 100$ dilution of the tested samples in per cent of the OD of a pool of sera containing rheumatoid factor. Values above $7 \%$ for $\operatorname{IgG}, 6 \%$ for $\operatorname{IgA}$, and $7 \%$ for IgM were considered as positive. ${ }^{15}$

PREPARATION OF LYMPHOCYTES

Lymphocytes were prepared from fresh heparinised venous blood samples by centrifugation on Metrizoate-Ficoll (Lymphoprep, Nyegaard) as described by Böyum. ${ }^{16}$ After washing, the cells in the intermediary phase were suspended in minimal essential medium (MEM) and used for lymphocyte stimulation tests with various mitogens and arterial antigens (see below).

\section{MITOGENS}

Phytohaemagglutinin (PHA) (Wellcome Ltd, Beckenham, Kent, England) was used in a final concentration of 1:100. Concanavalin-A (con-A) (Miles-Yeda Ltd, Rehovot, Israel) was used in a final concentration of $75 \mu \mathrm{g} / \mathrm{ml}$. Pokeweed mitogen (PWM) (Grand Island Biological Co, Paisley, Scotland) was used in a final concentration of $1: 10$.

Arterial antigens were prepared from aortic tissues obtained from a 20-year-old man who was killed in an accident and from a 50-year-old woman who had died from a brain tumour. The tissues were frozen within 3 and 12 hours respectively after death and stored at $-70^{\circ} \mathrm{C}$. After thawing, the tissue was first cut into small pieces with scissors, dispersed in an equal volume of PBS, then finely dispersed in an Omnimixer. The mixture was centrifuged at $23500 \mathrm{~g}$ (14 $000 \mathrm{rpm}$ ) for 30 minutes. The clear supernatant was stored frozen in suitable portions at $-20^{\circ} \mathrm{C}$ until used. Another piece of aortic tissue was treated as described above, but after grinding in the Omnimixer the tissue homogenate was subjected to freeze-pressing in an X-press. ${ }^{17}$ The freeze-pressed material was centrifuged at $23050 \mathrm{~g}$ for 30 minutes and the clear supernatant frozen and stored at $-20^{\circ} \mathrm{C}$. The sediment was suspended in an equal volume of MEM, and after division into suitable portions it was frozen and stored at $-20^{\circ} \mathrm{C}$. All 3 antigen preparations were used undiluted and diluted $1: 10$, $1: 100$, and $1: 1000$ in lymphocyte stimulation tests.

\section{LYMPHOCYTE STIMULATION TESTS}

Lymphocyte stimulation was performed according to the routine procedures of the immunological laboratory. Briefly, washed lymphocytes were suspended in Mishell-Dutton medium ${ }^{18}$ supplemented with $10 \%$ pooled human AB serum, $2 \mathrm{mM}$ 1-glutamine, $100 \mathrm{U} / \mathrm{ml}$ penicillin, $100 \mu \mathrm{g} / \mathrm{ml}$ streptomycin, and $20 \mathrm{mM}$ Hepes buffer, and adjusted to a concentration of $2 \times 10^{6}$ cells. Cultivations were performed in Linbro Tissue Culture grade microtitre plates at $37^{\circ} \mathrm{C}$ in air containing $5 \% \mathrm{CO}_{2} .10 \mu \mathrm{l}$ of the mitogens or arterial antigen preparations were 
added to $0.2 \mathrm{ml}$ of the lymphocyte suspensions. Each mitogen and the different antigen dilutions were tested in triplicate. $1 \mu \mathrm{Ci}{ }^{3} \mathrm{H}$-thymidine (Radiochemical Centre, Amersham, Bucks) was added to each well on the third day of culture for PHA and con-A and on the sixth day for PWM and arterial antigens. After further incubation overnight the cultures were harvested, and the incorporated

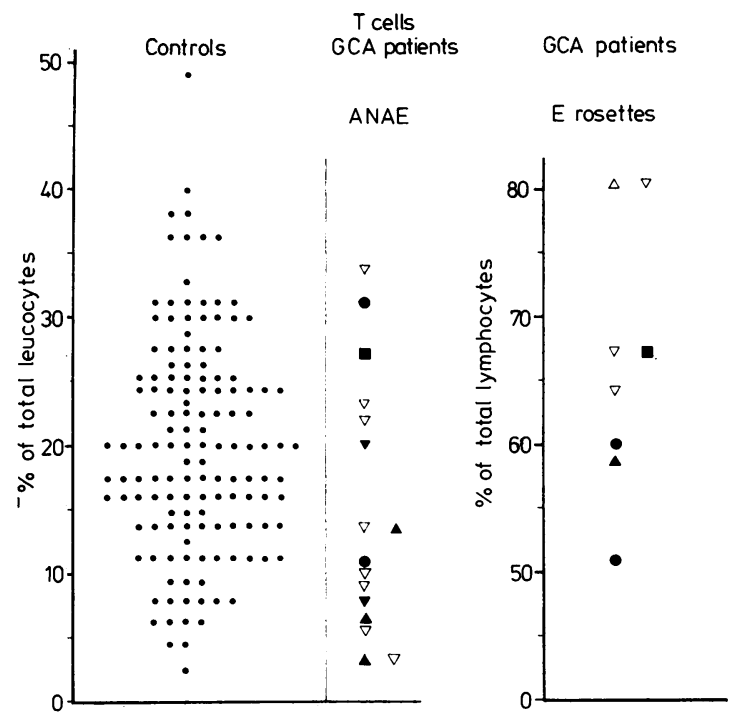

Fig. 1 Prevalence of T cells in patients with GCA and controls. $\mathbf{O}=$ temporal arteritis, $\Delta=$ temporal arteritis and polymyalgia rheumatica, $\nabla=$ polymyalgia rheumatica, $\square=$ general symptoms. Filled symbols represent biopsy-positive cases. radioactivity was determined by liquid scintillation counting. The stimulation index is given as the ratio between means for triplicates obtained in cultures with and without mitogens or antigens.

\section{T LYMPHOCYTES}

Owing to a change of routine laboratory procedures during the course of this investigation $T$ cells were quantitated by 2 different methods during different phases of the study. ANAE ( $\alpha$-naphthyl acetate esterase) staining was performed on peripheral blood as described by Mueller et al. ${ }^{19}$ The number of ANAE-positive cells is given as a percentage of the total number of white blood cells. E rosettes were determined as described by Jondal et al., ${ }^{20}$ and the number of $T$ cells is given as a percentage of the number of lymphocytes.

\section{STATISTICS}

Pitman's nonparametric permutation test was used for the statistical analysis of possible differences between patients and controls in the prevalence of $\mathrm{T}$ cells and the results of lymphocyte stimulation tests.

\section{Results}

Immune complexes containing IgM were found in serum from 2 out of 15 patients studied $(13 \%)$ and in 5 of the 94 controls $(5 \%)$. None of the patients had immune complexes containing IgG or IgA. Rheumatoid factors (RF) were studied in 27 patients. In 1 patient RF of all 3 immunoglobulin classes studied were demonstrated, whereas 1 patient had RF of the
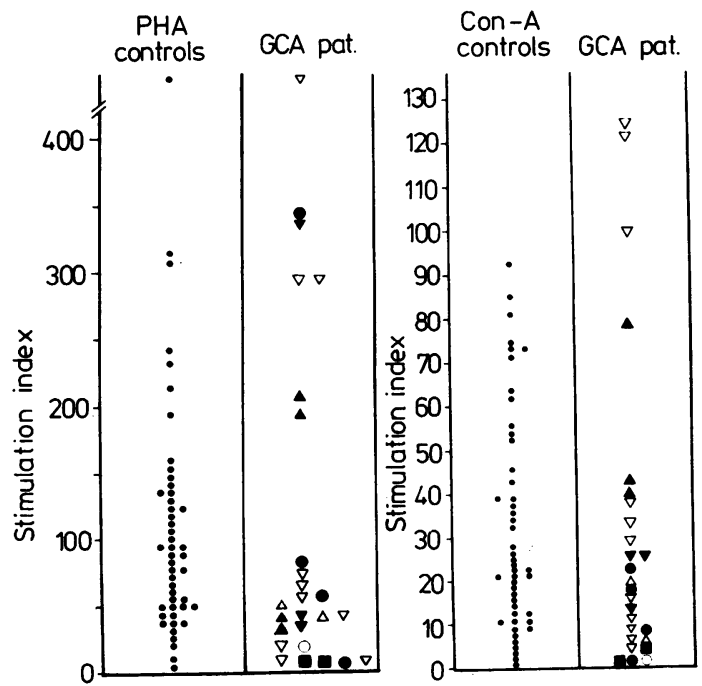

PWM

controls GCA pat

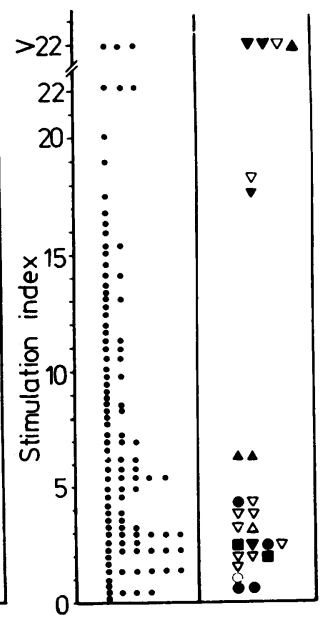

Fig. 2 Stimulation indexes for lymphocytes in blood from patients with $G C A$ and controls obtained by phytohaemagglutinin $(\mathrm{PHA})$, concanavalin- $A$ (con- $A)$, and pokeweed mitogen $(P W M)$. $\mathrm{O}=$ temporal arteritis, $\Delta=$ temporal arteritis and polymyalgia rheumatica, $\nabla=$ polymyalgia rheumutica, $\square=$ general sympioms. Filled symbols represent biopsy-positive cases. 
IgG class only. In the control group 10 individuals out of $94(11 \%)$ had RF of IgG and IgM classes and $7(7 \%)$ out of 94 had RF of the IgA class.

The prevalence of $\mathrm{T}$ cells wes determined in 17 patients by the ANAE technique and in 8 patients by the $E$ rosette technique. The distributions of $T$ cells among patients and controls are shown in Fig. 1. No statistically significant difference between the patients and the control group was revealed.

Lymphocyte stimulation tests with PHA, con-A, and PWM were performed on 25 patients. Fig. 2 gives a graphic illustration of the results obtained. There were no significant differences between patients and controls for any of the studied mitogens.

Lymphocyte stimulation with arterial homogenates was performed on 8 patients. In no instance was the incorporation of ${ }^{3} \mathrm{H}$-thymidine significantly increased in samples exposed to the arterial homogenate compared with nonexposed lymphocytes.

\section{Discussion}

Light and electron microscopic studies of the temporal artery in patients with GCA have revealed destruction of the internal elastic membrane with accumulation of mononuclear cells and giant cells. ${ }^{21}{ }^{22}$ These observations form the basis of the hypothesis that immunological mechanisms participate in the damage to the arterial wall. This hypothesis has later been supported by findings of immunoglobulins in the arterial wall, first reported by Sauerbruch et al. ${ }^{23}$ and later confirmed by other workers. $^{624}$ Waaler et al. ${ }^{7}$ have also demonstrated anti-immunoglobulin (rheumatoid factor) in temporal artery biopsies from patients with GCA. In a recent study by Plouvier et al. ${ }^{25}$ immunoglobulins were demonstrated in the temporal artery not only of patients with GCA but also of patients with other collagen diseases. Others, however, have failed to find immunoglobulin in artery biopsies. ${ }^{26}$ The finding of immunoglobulin in the temporal artery has been interpreted as being due to either deposition of circulating immune complexes or antigen-antibody reactions in the arterial wall. One aim of this study was therefore to demonstrate the presence of circulating immune complexes.

However, it was impossible to demonstrate circulating immune complexes in GCA patients more often than in controls by the ELISA technique employed. Our findings therefore do not support the hypothesis that circulating immune complexes participate in the pathogenesis of GCA. However, there are certain difficulties involved in the demonstration of circulating immune complexes, and many methods have been developed for this purpose. Recently published results from an extensive collaborative study ${ }^{27}$ showed that different methods give varying results in different diseases. As the method used in this study gives a high frequency of positive results for immune complexes containing IgG and IgA in patients with systemic lupus erythematosus and for immune complexes containing IgG in patients with rheumatoid arteritis, ${ }^{15}$ we conclude that immune complexes of this type are not present in sera from GCA patients. However, this does not exclude the possibility of demonstrating complexes with other properties by other techniques. Recently Papaioannou et al. ${ }^{29}$ found raised levels of immune-complex-like material in sera from patients with active GCA using the Raji cell radioimmunoassay.

The prevalence of rheumatoid factor in serum from patients with GCA has been reported to be as low as in serum from healthy persons of the same age when the Waaler-Rose test was used. ${ }^{28}$ The findings of anti-immunoglobulin activity, mainly of IgA type, in the arterial wall reported by Waaler et $a .^{7}$ stimulated us to use the ELISA in order to search for rheumatoid factors of different Ig classes in serum. With this test rheumatoid factors can be demonstrated in a high percentage of patients with rheumatoid arthritis. ${ }^{15}$ We conclude that the prevalence of rheumatoid factor of any Ig class in blood from GCA patients is not higher than in blood from randomly selected individuals of the same age.

The finding of mononuclear cell infiltration in the damaged artery, together with the finding of Hazleman et al. ${ }^{8}$ that lymphocytes in peripheral blood can be stimulated by arterial antigen in patients with GCA, has suggested that cell mediated immune mechanisms may be involved in GCA. Our results indicate that the prevalence of $T$ cells in blood is not significantly different in a group of GCA patients as compared with a group of healthy people of the same age. The reactivity to the mitogens PHA, con-A, and PWM does not seem to differ between untreated GCA-patients and controls. Our results are in accordance with those of Papaioannou et al., ${ }^{9}$ who found a normal prevalence of $E$ rosette forming cells and a normal uptake of thymidine in GCA patients after stimulation by PHA, PPD, mumps, and candida antigens.

We have not been able to reproduce the results of Hazleman et al. ${ }^{8}$ concerning lymphocyte stimulation by arterial antigen in GCA patients. Two other groups $^{910}$ have also studied the proliferation of lymphocytes exposed to arterial wall homogenate without finding any difference between GCA patients and controls.

The conclusion we draw from the present study is that the immunological parameters we have investi- 
gated in patients with GCA seem to be normal as compared with a population sample of the same age. The aetiology and pathogenesis of this disease are still not understood. The light and electron microscopic findings of accumulation of mononuclear cells round the destroyed internal elastic membrane and the rapid beneficial effect of corticosteroids warrant further immunological studies on patients with GCA.

\section{References}

1 Mumenthaler M. Giant cell arteritis (cranial arteritis, polymyalgia rheumatica). $J$ Neurol $1978 ; 218$ : 219-36.

2 Ettlinger R E, Hunder G G, Ward L E. Polymyalgia rheumatica and giant cell arteritis. Ann Rev Med 1978; 29: 15-22.

3 Liang G C, Simkin P A, Hunder G G, Wilske K R, Healey $L$ A, Familial aggregation of polymyalgia rheumatica and giant cell arteritis. Arthritis Rheum 1974; 17: 19-24.

4 Mowat A G, Hazleman B L. Polymyalgia rheumatica-a clinical study with particular reference to arterial disease. J Rheumatol 1974; 1: 190-202.

5 Malmvall B E, Bengtsson B $\AA$, Kaijser B, Nilsson L $\AA$, Alestig K. Serum levels of immunoglobulin and complement in giant cell arteritis. JAMA 1976; 236: 1876-78.

6 Liang G G, Simkin P A, Mannik M. Immunoglobulins in temporal arteries-an immunofluorescent study. Ann Intern Med 1974; 81 : 19-24.

7 Waaler E, Tönder O, Milde E J. Immunological and histological studies of temporal arteries from patients with temporal arteritis and/or polymyalgia rheumatica. Acta Path Microbiol Scand, 1976; Sect. A, 84: 55-63.

8 Hazleman B L, MacLennan I C M, Esiri M M. Lymphocyte proliferation to artery antigen as a positive diagnostic test in polymyalgia rheumatica. Ann Rheum Dis $1975 ; 34$ : 122-7.

9 Papaioannou C C, Hunder G G, McDuffie F C. Cellular immunity in polymyalgia rheumatica and giant cell arteritis-lack of response to muscle or artery homogenates. Arthritis Rheum 1979; 22: 740-5.

10 Zilko P, Currey H L F, Vernon-Roberts B. Polymyalgia rheumatica (PMR) and giant cell arteritis: lack of response of peripheral blood lymphocytes to arterial wall homogenate. Ann Rheum Dis 1977; 36: 286-7.

11 Malmvall B E, Bengtsson B A. Giant cell arteritis. Clinical features and involvement of different organs. Scand $J$ Rheumatol 1978; 7 : 154-8.

12 Malmvall B E, Bengtsson B $\AA$, Alestig K, Iwarson S, Bojs G. The clinical pictures of giant cell arteritis, temporal arteritis, polymyalgia rheumatica and fever of unknown origin. Postgrad Med 1980; 67: 141-8.

13 Svanborg A. Seventy-year-old people in Gothenburg-a population study in an industrialized Swedish city II. General presentation of social and medical conditions. Acta Med Scand 1977; Suppl. 611 : 3-37.
14 Ahlstedt S, Hanson L $\AA$, Wadsworth C. A Clq Immunosorbent assay compared with thin-layer gel filtration for measuring IgG aggregates. Scand J Immunol 1976; 5: 193-8.

15 Bjursten L M, Ahlstedt S, Hanson L A. Immunecomplexes and rheumatoid factors in systemic lupus erythematosus and rheumatoid arthritis recorded with enzyme-linked immunosorbent assays (ELISA). Submitted for publication.

16 Böyum A. Separation of leukocytes from blood and bone marrow. Scand J Clin Lab Invest 1968; 21 : (supple. 97): 31.

17 Edebo L. A new press for the disruption of microroganisms and other cells. $J$ Biochem Microbiol Technol Eng $1960 ; 2$ : 453-79.

18 Mishell R I, Dutton R W. Immunization of dissociated spleen cell cultures from normal mice. J Exp Med 1967; 126: 423-42.

19 Mueller J, Brun del R G, Buerki H, Keller H U, Hess M W, Cottier H. Nonspecific acid esterase activity: a criterion for differentiation of $T$ and $B$ lymphocytes in mouse lymph nodes. Eur J Immunol 1975; 5: 270-4.

20 Jondal M, Holm G, Wigzell H. Surface markers on human $\mathrm{T}$ and $\mathrm{B}$ lymphocytes. I A large proportion of lymphocytes forming non-immune rosettes with sheep red blood cells. J Exp Med 1972; 136: 207-15.

21 Ostberg G. On arteritis with special reference to polymyalgia arteritica. Acta Pathol Microbiol Scand 1973; Sect. A, suppl 237: 21-2.

22 Parker F, Healey L A, Wilske K R, Odland G F. Light and electron microscopic studies on human temporal arteries with special reference to alterations related to senescense, artherosclerosis and giant cell arteritis. Am J Pathol 1975; 79: 57-80.

23 Sauerbruch T, Stuhligen B, Kaess H. Immunhistologische Untersuchungen bei einem Fall von Reisenzellarteritis (arteritis temporalis). Dtsch Med Wochenschr 1973; 98: 283-4.

24 Park J R, Hazleman B L. Immunological and histological study of temporal arteries. Ann Rheum Dis 1978; 37: 238-43.

25 Plouvier B, Francois M, Wattre P, Francois P, Devulder B. Examen en immunofluorescence directe de coupes d'artère temporale. Nouv Presse Med 1978; 7: 1719-21.

26 Horwitz H M, Pepe P F, Johnsrude I S, McCoy R C, Jackson D C, Farmer J C. Temporal arteriography and immunofluorescence as diagnostic tools in temporal arteritis. J Rheumatol 1977; 4: 76-85.

27 Lambert P H, Dixon F J, Zubler R H, et al. A collaborative study for the evaluation of eighteen methods for detecting immune complexes in serum. Clin Lab Immunol $1978 ; 1: 1$.

28 Hamrin B. Polymyalgia arteritica. Acta Med Scand 1972; Suppl. 533: 123-4.

29 Papaioannou C C, Gupta $R$ C, Hunder G G, N McDuffie F C. Circulating immune complexes in giant cell arteritis and polymyalgia rheumatica. Arthritis Rheum 1980; 23: 1021-5. 